\title{
PERANCANGAN APLIKASI INVENTORY BARANG PADA CV. MR LESTARI BERBASIS WEB
}

\author{
Rehulina Tarigan', Deni Ardiansyah ${ }^{2}$ \\ Fakultas Ilmu Komputer Universitas Banten Jaya \\ Jl. Ciwaru Raya No. 73 Kota Serang - Banten \\ $\underline{\text { rtarigan1971@gmail.com }}^{1}$
}

\begin{abstract}
ABSTRAK
Perkembangan Teknologi Informasi dari tahun ke tahun yang semakin cepat dan menjadi tantangan berat bagi pengguna teknologi informasi itu sendiri. Perkembangan ini juga mendorong setiap sektor organisasi ataupun usaha baik formal maupun informal atau lembaga lainnya untuk dapat memanfaatkannya sebagai penunjang pengembangan usaha atau kinerja sehingga menghasilkan informasi yang cepat, tepat dan akurat. CV. MR Lestari adalah usaha kecil menengah di bidang pembuatan dan supplier pakaian dan aksesoris. Penulis mencoba menganalisa dan melihat sistem yang ada, ternyata masih mengalami beberapa masalah dan kendala, salah satunya yaitu belum adanya sistem informasi berbasis komputer yang dapat membantu mengelola data barang pada CV. MR Lestari. Selama ini semua pencatatan barang masuk, barang keluar dan stok dilakukan secara manual dengan menuliskan datanya pada buku besar. Pencatatan manual ini menimbulkan beberapa masalah seperti membutuhkan waktu lama dalam mencari histori data karena harus memeriksa halaman per halaman dari buku besar untuk mencari data suatu item. Pemilik juga harus meminta terlebih dahulu kepada admin atau pegawainya berkaitan dengan kebutuhan laporan data barang masuk, barang keluar dan jumlah stok di gudang. Hal ini membutuhkan waktu lama karena laporan tidak bersifat realtime. Berdasarkan hal tersebut, maka perlu dicari pemecahan dalam mengatasi masalah yaitu perlu adanya sistem informasi berbasis komputer sehingga dapat membantu mengelola data barang sehingga menjadi laporan dengan cepat (realtime), tepat dan akurat sesuai dengan yang diharapkan. Metode pengembangan sistem yang digunakan adalah metode waterfall dan pemodelan menggunakan UML (Unified Modeling Language) yang diharapkan dapat membantu untuk perancangan aplikasi ini. Hasil dari pengembangan sistem dapat memberikan laporan yang tepat, akurat dan bersifat realtime bagi user yang membutuhkan sesuai dengan otorisasi yang diberikan oleh sistem aplikasi.
\end{abstract}

Kata kunci : aplikasi, inventori.

\section{PENDAHULUAN}

Seiring dengan perkembangan teknologi khususnya teknologi informasi yang begitu pesat, maka dunia usahapun dituntut untuk bersaing secara kompetitif, agar kebutuhan manajemen dapat bekerja secara efektif dan efisien. Di sinilah informasi memegang peranan penting, karena informasi dibutuhkan oleh semua pihak, baik individu maupun organisasi atau perusahaan. Dahulu manusia menyimpan semua informasi dan dokumen menggunakan buku yang disimpan dalam lemari dokumen, maka sekarang berubah menggunakan komputer untuk menyimpan data-data suatu 
perusahaan. Setiap perusahaan memiliki kebutuhan informasi yang berbeda-beda untuk meningkatkan produktivitas perusahaan tersebut.

Peranan komputer di era sekarang ini sangat penting dalam pengolahan informasi di perusahaan karena dengan menggunakan pengolahan informasi yang berbasis komputer akan mampu menghasilkan suatu informasi yang tepat, akurat dan bermanfaat bagi organisasi maupun perusahaan. Salah satu teknologi informasi tersebut adalah sistem infomasi inventori yaitu sistem informasi untuk mengolah data penyimpanan barang. Sistem informasi ini sangat penting karena data penyimpanan barang sangat diperlukan pada saat pembuatan laporan barang untuk harian, bulanan maupun tahunan.

CV. MR Lestari merupakan usaha kecil menengah di bidang pembuatan dan merupakan supplier atau pemasok pakaian dan aksesoris. CV. MR Lestari berdomisili di Jl. Raya Labuan Km 13 Cipeucang Menes, Palanyar, Pandeglang Banten. Dalam pengelolaan data barang dan data pesanan $\mathrm{CV}$. MR Lestari belum terkelola dengan baik. Waktu yang diperlukan untuk pembuatan laporan stok barang relatif lama karena belum ada sistem pencatatan secara komputerisasi. Sebelum barang hasil produksi masuk ke dalam gudang, maka harus dilakukan pemeriksaan satu persatu jumlah stok barang sebelumnya di gudang lalu ditambahkan dengan barang hasil produksi. Pemesanan barang yang dilakukan oleh pembeli masih menggunakan sistem telepon atau SMS (Short Message Service) dan dicatat manual. Pesanan tersebut hanya diketahui oleh pemilik selaku orang yang dihubungi oleh pemesan barang dan pemilik harus mengelola sendiri pesanan barang tersebut. Pada saat terjadinya pesanan barang dalam jumlah cukup banyak, pemilik tidak mampu menangani pesanan tersebut. Hal ini disebabkan karena pemesanan barang dilakukan melalui sistem telepon atau SMS dan pencatatan pesanan masih manual, sehingga sering terjadinya kesalahan dalam pemenuhan pesanan. Data pesanan belum otomatis menjadi laporan sehingga pada saat pembuatan laporan membutuhkan waktu yang cukup lama untuk merekap data menjadi laporan. Untuk membantu mengatasi hal tersebut, perlu adanya sistem aplikasi berbasis komputer berbasis web yang dapat membantu permasalahan inventori yang dialami oleh CV. MR Lestari.

Aplikasi inventori berbasis web ini bisa dijadikan sebagai solusi permasalahan, karena aplikasi ini dapat lebih detail dan lengkap untuk pengelolaan informasi seputar penyimpanan barang dan dapat membantu pada saat pembuatan 
laporan berdasarkan data yang akurat. Berdasarkan latar belakang masalah yang telah dikemukakan di atas masalah dapat diidentifikasi sebagai berikut:

- Pada saat banyak pesanan masuk sering terjadinya kesalahan pesanan, karena pemesanan barang yang dilakukan oleh pembeli menggunakan sistem telepon atau SMS (Short Message Service) terbatas dan dicatat manual.

- Pembuatan laporan membutuhkan waktu yang cukup lama untuk rekap data pesanan atau memeriksa satu persatu stok barang yang ada digudang.

- Belum adanya sistem informasi berbasis komputer yang dapat membantu mengelola data pada CV. MR Lestari.

Pada tulisan ini, penulis melakukan pembatasan masalah berupa: perancangan aplikasi mencakup pengelolaan data barang, pembuatan laporan stok opname, laporan barang masuk dan laporan barang keluar. Adapun hasil yang diharapkan dari penelitian ini adalah adanya sebuah aplikasi sistem inventori yang dapat mengelola data CV. MR Lestari. Aplikasi sistem inventori ini dapat memberikan data barang beserta jumlah yang akurat karena tersistem dan terstruktur dalam suatu database yang terintegrasi.

\section{METODE PENELITIAN}

Dalam membangun sistem aplikasi inventori ini, penulis dan tim menggunakan metodologi pengumpulan data sebagai berikut:

- Pengamatan (Observasi), yaitu mengadakan peninjauan langsung terhadap kegiatan dan sistem yang berjalan sehingga penulis dapat memahami proses bisnis yang ada pada CV. MR Lestari.

- Wawancara (Interview), yaitu melakukan tanya jawab secara langsung dengan pihak-pihak yang mengetahui tentang permasalahan yang ada di CV. MR Lestari. Dari wawancara, tim penulis dapat memperoleh sejumlah data dan informasi yang diperlukan. Selain itu, penulis juga memperoleh sejumlah bentuk laporan yang diperlukan baik oleh pemilik maupun karyawan CV. MR Lestari.

- Studi Pustaka, yaitu teknik mempelajari sejumlah teori yang ada mengenai terminologi atau istilah dan pengelolaan sistem informasi yang berhubungan dengan Aplikasi Inventori. 
Adapun metodologi pengembangan yang penulis gunakan adalah metode waterfall. Metode ini sudah digunakan secara luas untuk pengembangan aplikasi perangkat lunak dan merupakan model klasik dari rekayasa perangkat lunak yang banyak digunakan dalam berbagai macam proyek baik pemerintahan maupun perusahaan besar swasta lainnya. Metode ini sangat terstruktur, tertapi cenderung bersifat linier dan tidak fleksibel. Metode ini memerlukan pendekatan yang sistematis dan sekuensial di dalam pengembangan sistem perangkat lunak. ${ }^{[1]}$ Sommerville (2011:31) dalam bukunya mengungkapkan bahwa tahapan dari model waterfall meliputi aktifitas sebagai berikut:

a) Requirements analysis and definition.

Layanan sistem, kendala, dan tujuan ditetapkan dengan cara berkonsultasi dengan pengguna sistem. Semua kebutuhan itu didefinisikan secara terperinci dan berfungsi sebagai spesifikasi sistem.

b) System and software design.

Proses desain sistem, mengalokasikan persyaratan untuk sistem perangkat keras atau perangkat lunak dengan membangun arsitektur sistem secara keseluruhan. Desain perangkat lunak melibatkan proses mengidentifikasi dan menggambarkan abstraksi dasar sistem perangkat lunak dan hubungannya.

c) Implementation and unit testing

Selama tahap ini, desain perangkat lunak diwujudkan sebagai satu set program atau unit program. Pengujian unit melibatkan melakukan verifikasi setiap unit sehingga memenuhi spesifikasi perangkat lunak yang diharapkan.

d) Integration and system testing

Unit program baik secara individu atau program terintegrasi diuji sebagai sistem yang lengkap untuk memastikan bahwa persyaratan perangkat lunak telah terpenuhi. Setelah pengujian, sistem perangkat lunak dikirim ke pelanggan.

e) Operation and maintenance

Biasanya (walaupun tidak harus), ini adalah fase siklus hidup terpanjang. Sistem diinstal dan digunakan secara praktis. Pemeliharaan melibatkan koreksi kesalahan yang tidak ditemukan sebelumnya pada tahap analisis sampai tahap implementasi. Di samping itu dilakukan peningkatan implementasi sistem ketika persyaratan kebutuhan yang baru telah ditemukan. 
Adapun diagram dari tahapan itu digambarkan oleh Sommerville (2011:30) sebagai berikut:

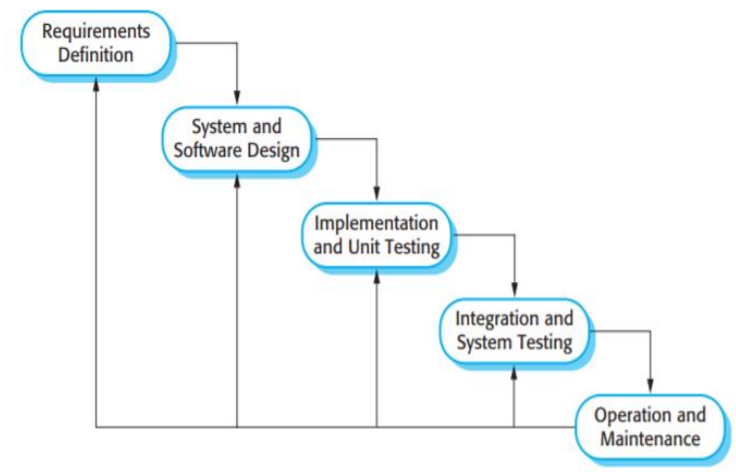

Gambar 1. Model Waterfall

Berdasarkan motodologi yang dikemukakan oleh Sommerville seperti gambar di atas, maka penulis melakukan tahapan untuk mengumpulkan semua persyaratan sistem sesuai dengan kebutuhan dari pengguna. Seperti sudah dijelaskan sebelumnya, maka tahapan pengumpulan data dilakukan dengan observasi dan wawancara langsung ke pengguna yang akan memakai sistem. Pada tahapan ini, penulis memperoleh gambaran proses bisnis yang ada di lapangan, memperoleh sejumlah data berdasarkan format beberapa laporan yang user gunakan selama ini. Setelah data dikumpulkan, lalu dianalisa bagaimana hubungan antara data yang satu dengan data yang lain, memperkirakan seperti apa screen atau antar muka yang bagus dan sesuai kebutuhan user.

Setelah tahap analisa, maka penulis dan tim akan melakukan perancangan basis data dengan menerapkan prinsip normalisasi sehingga semua tabel atau entitas yang dipergunakan sudah dalam bentuk normal. Normalisasi merupakan parameter digunakan untuk menghindarari duplikasi terhadap tabel dalam basi data dan juga merupakan proses mendekomposisikan sebuah tabel yang masih memiliki beberapa anomali atau ketidak wajaran sehingga menghasilkan tabel yang lebih sederhana dan struktur yang bagus, yaitu sebuah tabel yang tidak memiliki data redundancy dan memungkinkan user untuk melakukan insert, delete, dan update pada baris (record) tanpa menyebabkan inkonsistensi data (Triyono, 2011). Selain perancangan basis data, juga dilakukan perancangan antar muka dengan pengguna serta perancangan laporanlaporan yang secara otomatis dapat diperoleh dari sistem inventori yang akan 
dikembangkan. Penulis akan membahas dan menunjukkan hasil dari proses atau tahapan aktifitas pengembangan perangkat lunak pada bagian Hasil dan Pembahasan.

Untuk mendapatkan spesifikasi perangkat lunak yang diharapkan sesuai dengan keinginan dan kebutuhan pengguna, tim peneliti melakukan pemodelan secara visual. Pemodelan visual adalah proses penggambaran informasi-informasi secara grafis dengan notasi-notasi baku yang telah disepakati sebelumnya (Nugroho, 2005:17). Untuk melakukan pemodelan proses bisnis yang ada pada sistem inventori CV. MR Lestari, maka penulis menggunakan notasi-notasi UML (Unified Modeling Language).

Unified Modeling Language (UML) adalah bahasa pemodelan visual yang bersifat general-purpose, yang digunakan untuk menentukan, membuat visualisasi, membangun serta membuat dokumentasi artefak dari sistem perangkat lunak. Hal ini menyangkut pemahaman tentang sistem yang harus dibangun. Pemodelan ini digunakan untuk memahami, melakukan perancangan, menelusuri, mengkonfigurasi, memelihara, dan mengontrol informasi tentang suatu sistem (Rumbaugh, 1999:3). UML views dapat digambarkan dalam berbagai diagram sebagai berikut ${ }^{[5]}$ :

- Static view dalam bentuk class diagram

- Use-case view dalam bentuk use-case diagram

- Implementation view digambarkan dalam bentuk componen diagram

- Deployment view digambarkan dalam bentuk deployment diagram

- $\quad$ State machine view digambarkan dalam bentuk statechart diagram

- Activity view dalam bentuk acivity diagram

- Interaction view dalam bentuk sequence diagram dan collaboration diagram

- Model management view dalam bentuk class diagram

Beberapa dari diagram tersebut di atas akan dipergunaka dalam tulisan ini diantaranya: use-case diagram, class diagram, activity diagram dan sequence diagram.

\section{HASIL DAN PEMBAHASAN}

Sebelum lebih lanjut membahas tentang hasil dari penelitian, maka penulis akan menjelaskan terlebih dahulu hasil analisa dari sistem yang berjalan. Analisis terhadap sistem yang sedang berjalan merupakan salah satu langkah untuk menentukan prosedur yang sedang dirancang, karena dengan analisa sistem kita dapat mengetahui kelebihan dan kekurangan dari sistem yang kita buat. Pada sistem yang 
sedang berjalan, sistem inventori barang pada CV. MR Lestari dicatat secara manual yaitu menggunakan buku besar dan sejumlah kertas, belum menggunakan pencatatan dengan komputer seperti aplikasi Ms. Excel. Hal ini sering menimbulkan proses pencatatan menjadi lambat sehingga informasi yang didapat tidak up to date.

\section{Hasil Analisa Dan Perancangan Sistem}

Setelah dilakukan analisa terhadap sistem yang berjalan, maka diperoleh beberapa hal yang ingin dicapai dari sistem inventori yang akan di kembangkan yaitu:

- Sistem informasi harus memberikan informasi yang cepat dan tepat secara terkomputerisasi. Jika selama ini, pemilik harus meminta terlebih dahulu laporan mengenai stok, jumlah barang masuk dan jumlah barang keluar kepada admin atau pegawainya, maka dengan adanya sistem ini diharapkan pemilik dapat mengetahui data stok, jumlah barang masuk maupun jumlah barang keluar secara realtime.

- Sistem informasi dapat memenuhi kebutuhan pengguna dari segi kemudahan pemakaian dan keakuratan laporan secara terkomputerisasi.

- Sistem dapat melakukan backup dan restore data.

Beberapa laporan yang dipergunakan seperti laporan barang masuk serta laporan barang keluar. Untuk input data ke sistem diperlukan user interface seperti:

- Input data barang masuk: bagian gudang menginput data barang masuk dan laporannya dikirim ke pemilik. Pemilik merekap data gudang sehingga menjadi laporan barang masuk.

- Input pesanan: pelanggan membeli pesanan kepada pemilik melalui telpon atau SMS, lalu pemilik mengolah data itu sehingga menjadi laporan barang keluar.

Pemodelan proses tersebut dapat digambarkan dengan use-case diagram. Use-case diagram bersifat statis. Diagram ini memperlihatkan himpunan use-case dan aktor. Diagram ini terutama sangat penting untuk mengorganisasi dan memodelkan perilaku dari suatu sistem yang dibutuhkan serta diharapkan pengguna (Nugroho, 2005:19). Adapun use-case diagram untuk proses pada sistem berjalan dapat digambarkan sebagai berikut: 


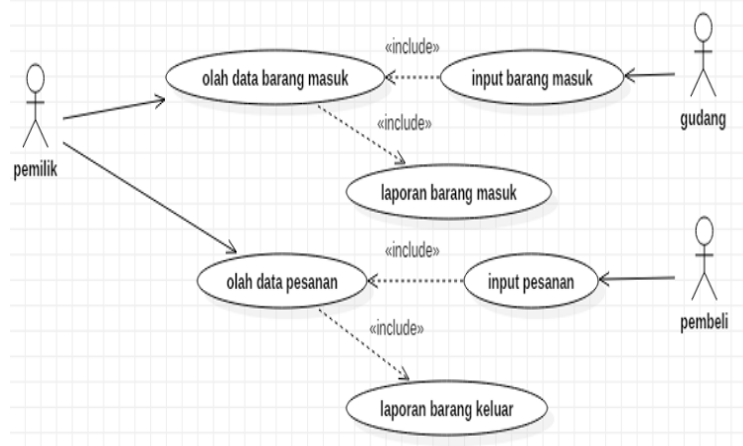

Gambar 2. Use-case sistem berjalan

Jika use-case diagram bersifat statis, maka activity diagram dan sequence diagram bersifat dinamis. Activity diagram memperlihatkan aliran dari suatu aktifitas ke aktifitas lainnya dalam suatu sistem. Sedangkan sequence diagram memperlihatkan interaksi yang menekankan pada pengiriman pesan (message) dalam suatu waktu tertentu ${ }^{[4]}$. Diagram-diagram berikut ini memperlihatkan pemodelan proses dalam bentuk activity diagram dan sequence diagram.

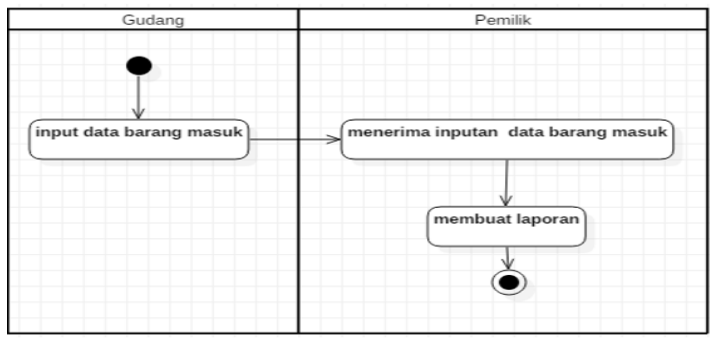

Gambar 3. Activity Diagram Mengolah Data Barang Masuk

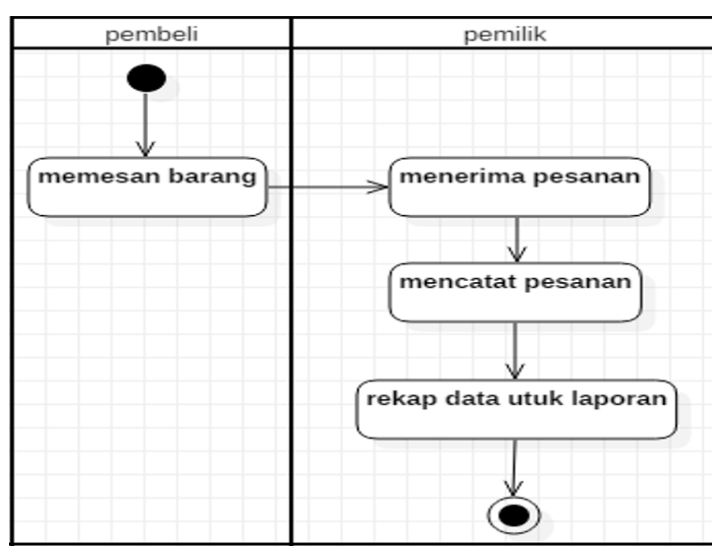

Gambar 4. Activity Diagram Mengolah Data Pesanan

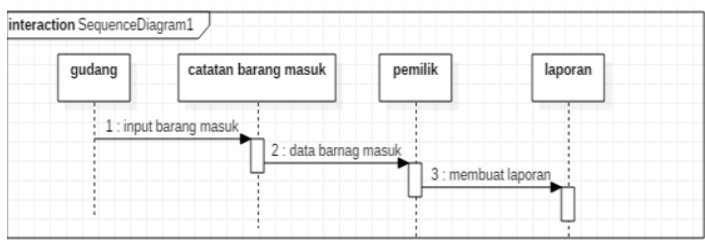

Gambar 5. Sequence Diagram Mengolah Data Barang Masuk

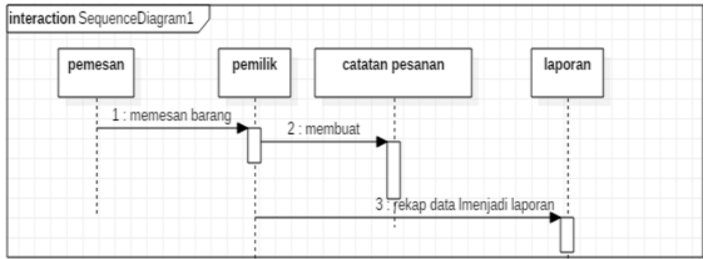

Gambar 6. Sequence Diagram Mengolah Data Pesanan 


\section{a. Pemodelan Proses Pada Sistem Yang Akan Dikembangkan}

Setelah melakukan analisa terhadap sistem yang berjalan, maka ada beberapa proses yang dilakukan perbaikan atau improvement, yaitu:

- Ada proses login

- Admin melakukan proses input data pesanan, data barang masuk, data master barang, data user, data pembeli, data pengirim, mengolah laporanlaporan dan mengolah data masuk yang diinput pihak gudang.

- Pemilik dapat input data master barang, data user, data pembeli, data pengirim serta menghasilkan beberapa report seperti: laporan barang keluar, laporan barang masuk dan laporan stock opname.

- Petugas gudang melakukan input barang masuk atau barang yang sudah selesai diproduksi.

- Pengirim akan memperoleh faktur pengiriman dari sistem.
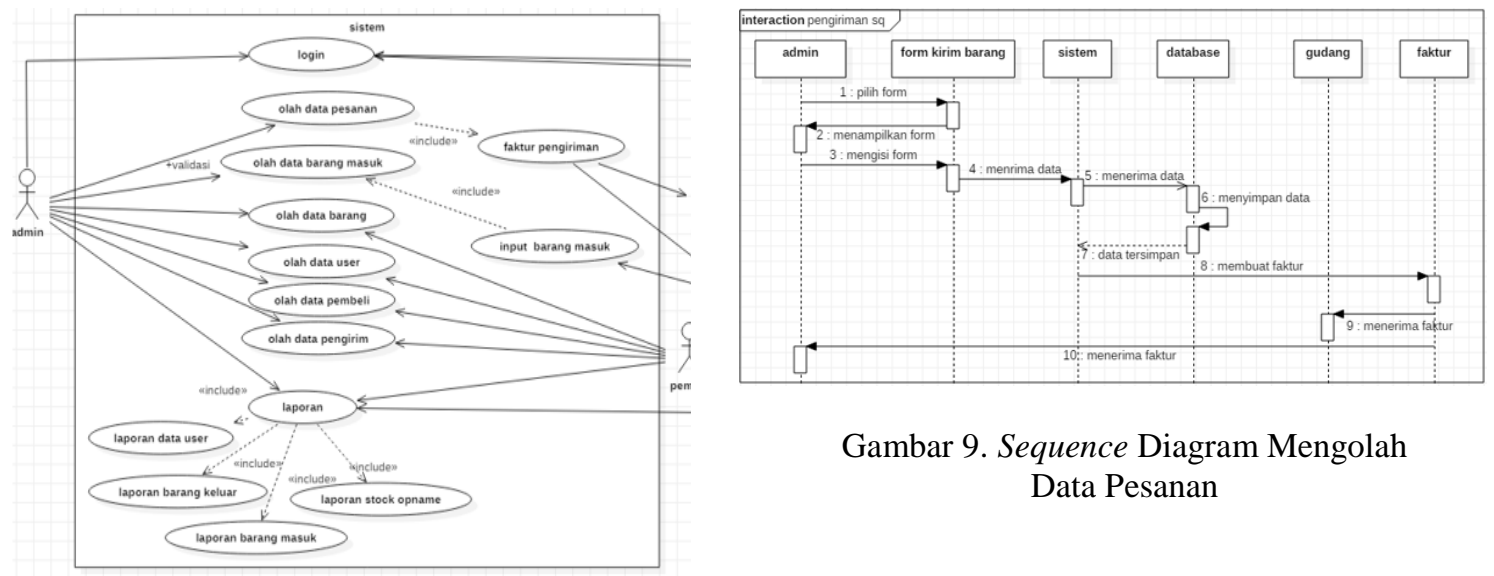

Gambar 9. Sequence Diagram Mengolah Data Pesanan

Gambar 7. Use-case Diagram Sistem Inventori CV. MR Lestari

Berikutnya secara berturut akan ditampilkan pemodelan sistem yang akan dibangun dengan menggunakan sequence diagram.
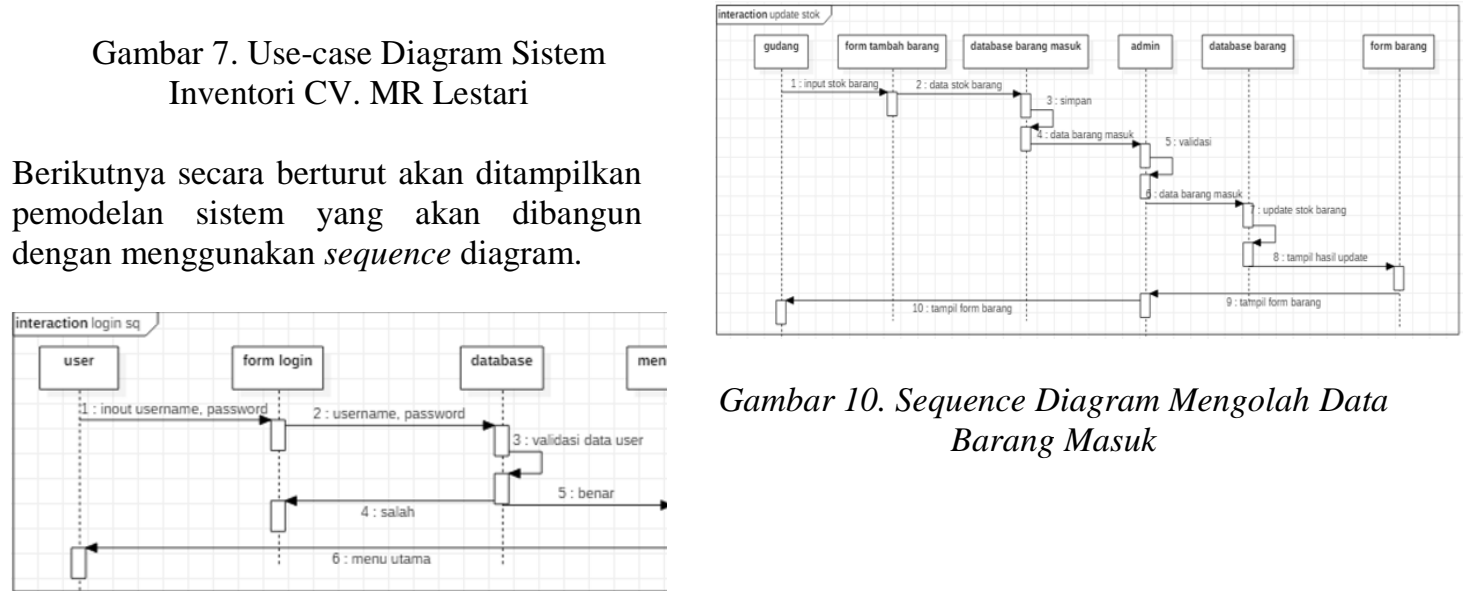

Gambar 10. Sequence Diagram Mengolah Data Barang Masuk

Gambar 8. Sequence Diagram Login 

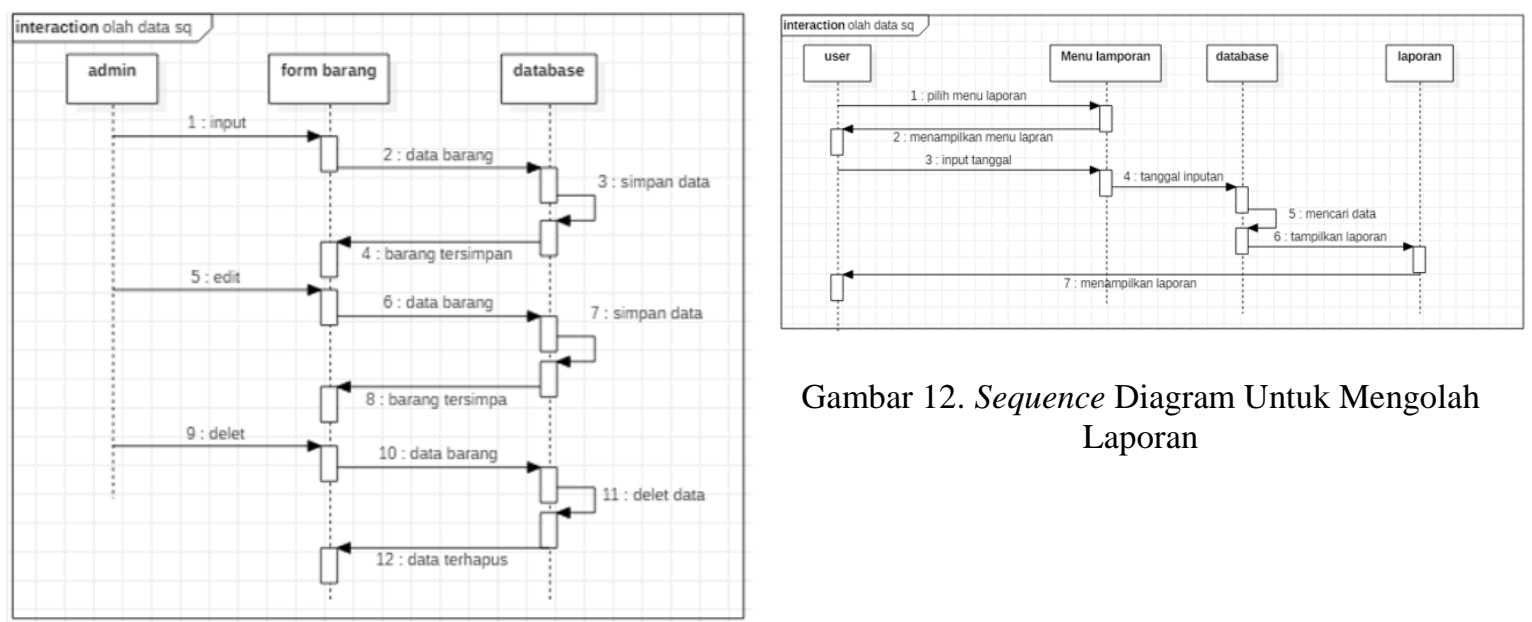

Gambar 12. Sequence Diagram Untuk Mengolah Laporan

Gambar 11. Sequence Diagram Mengolah Master Barang

\section{b. Perancangan Basis Data}

Pada perancangan basis data sistem inventori CV. MR Lestari menggunakan sebanyak tiga belas table atau entitas. Kalau dalam perancangan berorientasi objek sering disebut sebagai class. Oleh karena itu, berikut ini akan ditampilkan class diagram atau diagram kelas yang menunjukkan sejumlah class yang terlibat dan bagaimana hubungan atau relationship antara class. Nugroho (2005:110) mengungkapkan bahawa diagram kelas (class diagram) adalah diagram yang digunakan untuk menampilkan beberapa kelas serta paket-paket yang ada dalam sistem/perangkat lunak yang sedang kita kembangkan.

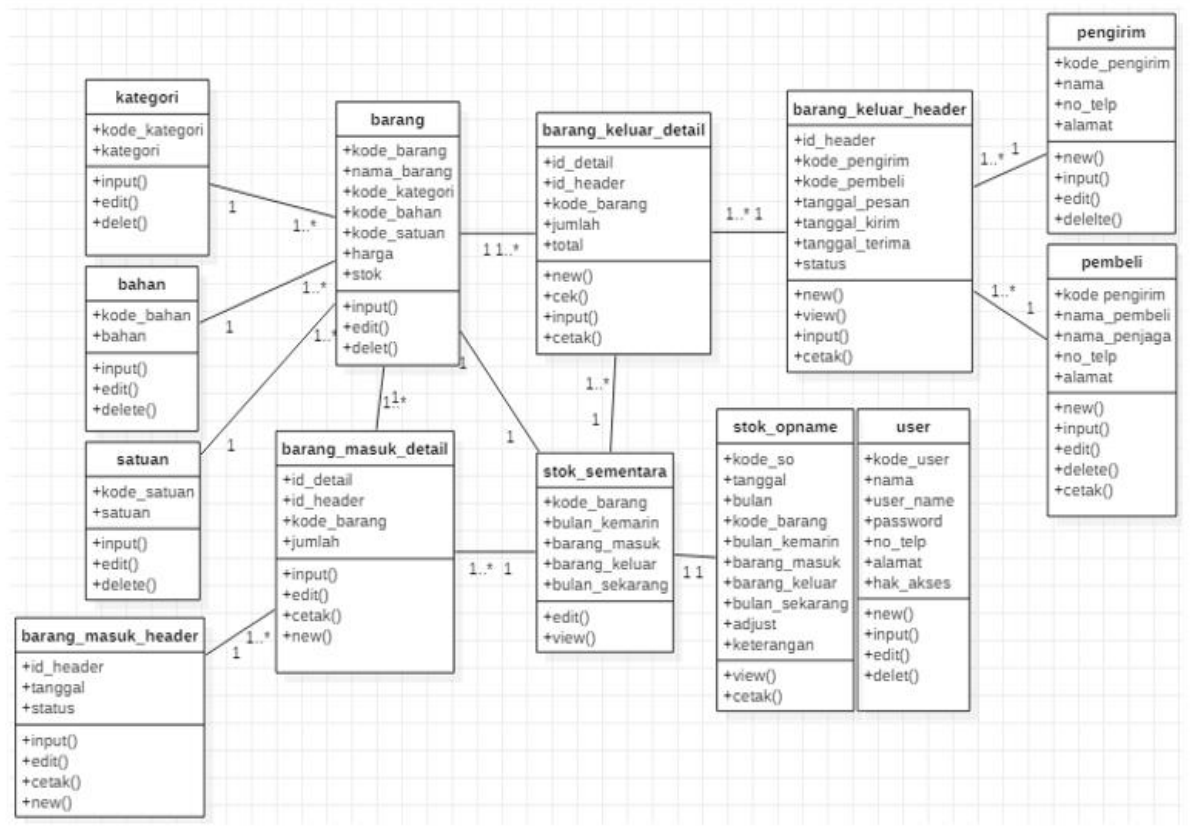

Gambar 13. Class Diagram 
Setiap kelas terdiri dari tiga bagian yaitu: nama kelas, atribut atau property dan operasi atau method. Berikut ini akan ditampilkan spesifikasi setiap class sebagai hasil rancangan pada sistem yang akan dikembangkan.

Tabel 1. Spesifikasi Kelas bahan

\begin{tabular}{|c|l|c|c|c|}
\hline \multicolumn{5}{|l|}{ JENIS KELAS : master } \\
\hline \multicolumn{4}{|l|}{ NAMA KELAS : bahan } \\
\hline \multicolumn{4}{|l|}{ PRIMARY KEY : kode_bahan } \\
\hline FORGN KEY: - \\
\hline NO & FIELD NAME & TYPE & WIDTH & KETERANGAN \\
\hline 1 & Kode_bahan & Int & 2 & - \\
\hline 2 & Bahan & Varchar & 50 & - \\
\hline
\end{tabular}

Tabel 2. Spesifikasi Kelas kategori

\begin{tabular}{|c|l|c|c|c|}
\hline \multicolumn{5}{|l|}{ JENIS KELAS : master } \\
\hline \multicolumn{5}{|l|}{ NAMA KELAS : kategori } \\
\hline \multicolumn{4}{|l|}{ PRIMARY KEY : kode_kategori } \\
\hline FORGN KEY: - \\
\hline NO & FIELD NAME & TYPE & WIDTH & KETERANGAN \\
\hline 1 & Kode_kategori & Int & 2 & - \\
\hline 2 & kategori & Varchar & 50 & - \\
\hline
\end{tabular}

Tabel 3. Spesifikasi Kelas satuan

\begin{tabular}{|c|c|c|c|c|}
\hline \multicolumn{5}{|c|}{ NAMA KELAS : satuan } \\
\hline \multicolumn{5}{|c|}{ PRIMARY KEY : kode_satuan } \\
\hline \multicolumn{5}{|c|}{ FORGN KEY:- } \\
\hline $\mathrm{NO}$ & FIELD NAME & TYPE & WIDTH & KETERANGAN \\
\hline 1 & Kode satuan & Int & 2 & - \\
\hline 2 & satuan & Varchar & 50 & - \\
\hline
\end{tabular}

Tabel 4. Spesifikasi Kelas barang

\begin{tabular}{|c|c|c|c|c|}
\hline \multicolumn{5}{|c|}{ JENIS KELAS : master } \\
\hline \multicolumn{5}{|c|}{ NAMA KELAS: barang } \\
\hline \multicolumn{5}{|c|}{ PRIMARY KEY : kode_barang } \\
\hline \multicolumn{5}{|c|}{ FORGN KEY:- } \\
\hline $\mathrm{NO}$ & FIELD NAME & TYPE & WIDTH & KETERANGAN \\
\hline 1 & Kode_barang & Int & 12 & - \\
\hline 2 & Nama_barang & Varchar & 50 & - \\
\hline 3 & Kode_kategori & Varchar & 25 & - \\
\hline 4 & Kode_bahan & Varchar & 25 & - \\
\hline 5 & Kode_satuan & Varchar & 25 & - \\
\hline 6 & Harga & Int & 15 & - \\
\hline 7 & Stok & Int & 3 & - \\
\hline
\end{tabular}

Tabel 5. Spesifikasi Kelas barang_masuk_header JENIS KELAS : transaksi

\begin{tabular}{|c|c|c|c|c|}
\hline \multicolumn{5}{|c|}{ NAMA KELAS: barang_masuk_header } \\
\hline \multicolumn{5}{|c|}{ PRIMARY KEY : Id_header } \\
\hline \multicolumn{5}{|c|}{ FORGN KEY: - } \\
\hline NO & FIELD NAME & TYPE & WIDTH & KETERANGAN \\
\hline 1 & Id_header & Varchar & 25 & - \\
\hline 2 & Tanggal & Date & & - \\
\hline 3 & Status & Varchar & 15 & - \\
\hline
\end{tabular}

Tabel 6. Spesifikasi Kelas barang_masuk_detail JENIS KELAS : transaksi

\begin{tabular}{|c|c|c|c|c|}
\hline \multicolumn{5}{|c|}{ NAMA KELAS: barang_masuk detail } \\
\hline \multicolumn{5}{|c|}{ PRIMARY KEY :- } \\
\hline \multicolumn{5}{|c|}{ FORGN KEY:- } \\
\hline NC & FIELD NAME & TYPE & WIDTH & KETERANGAN \\
\hline 1 & Id_detail & Varchar & 25 & - \\
\hline 2 & \begin{tabular}{|l|} 
Id_header \\
\end{tabular} & Date & & - \\
\hline 3 & Kode_barang & Int & 12 & - \\
\hline 4 & jumlah & Int & 3 & - \\
\hline
\end{tabular}

Tabel 7. Spesifikasi Kelas barang_keluar_header JENIS KELAS : transaksi

\begin{tabular}{|c|c|c|c|c|}
\hline \multicolumn{5}{|c|}{ NAMA KELAS : barang_keluar_header } \\
\hline \multicolumn{5}{|c|}{ PRIMARY KEY : Id_header } \\
\hline \multicolumn{5}{|c|}{ FORGN KEY:- } \\
\hline NO & FIELD NAME & TYPE & WIDTH & KETERANGAN \\
\hline 1 & Id_header & Varchar & 25 & - \\
\hline 2 & Kode_pengirim & Varchar & 5 & - \\
\hline 3 & Kode_pembeli & Varchar & 5 & - \\
\hline 4 & Tanggal_pesan & Date & & - \\
\hline 5 & Tanggal_kirim & Date & & - \\
\hline 6 & Tanggal_terima & Date & & - \\
\hline 7 & Status & int & 1 & - \\
\hline
\end{tabular}

Tabel 8. Spesifikasi Kelas barang_keluar_detail JENIS KELAS : transaksi

NAMA KELAS : barang_keluar_detail

PRIMARY KEY : -

FORGN KEY: -

\begin{tabular}{|c|l|c|c|c|}
\hline NO & FIELD NAME & TYPE & WIDTH & KETERANGAN \\
\hline 1 & Id_detail & Varchar & 25 & - \\
\hline 2 & Id_header & Varchar & 5 & - \\
\hline 3 & Kode_barang & Int & 12 & - \\
\hline 4 & Jumlah & Int & 3 & - \\
\hline 5 & total & Int & 15 & - \\
\hline
\end{tabular}


Tabel 9. Spesifikasi Kelas pembeli

\begin{tabular}{|c|l|c|c|l|}
\hline \multicolumn{4}{|l|}{ JENIS KELAS : master } \\
\hline \multicolumn{4}{l|}{ NAMA KELAS : pembeli } \\
\hline \multicolumn{4}{|l|}{ PRIMARY KEY : kode_pembeli } \\
\hline FORGN KEY: - \\
\hline NO & FIELD NAME & TYPE & WIDTH & KETERANGAN \\
\hline 1 & Kode_pembeli & Int & 12 & - \\
\hline 2 & Nama_Toko & Varchar & 50 & - \\
\hline 3 & Nama_penjaga & Varchar & 25 & - \\
\hline 4 & No_telp & Varchar & 25 & - \\
\hline 5 & Alamat & Varchar & 25 & - \\
\hline
\end{tabular}

Tabel 10. Spesifikasi Kelas pembeli

\begin{tabular}{|c|c|c|c|c|}
\hline \multicolumn{5}{|c|}{ JENIS KELAS : master } \\
\hline \multicolumn{5}{|c|}{ NAMA KELAS : pengirim } \\
\hline \multicolumn{5}{|c|}{ PRIMARY KEY : kode_pengirim } \\
\hline \multicolumn{5}{|c|}{ FORGN KEY: - } \\
\hline $\mathrm{NO}$ & FIELD NAME & TYPE & WIDTH & KETERANGAN \\
\hline 1 & Kode_pengirim & Varchar & 12 & - \\
\hline 2 & Nama & Varchar & 50 & - \\
\hline 3 & No_telp & Varchar & 15 & - \\
\hline 4 & Alamat & Text & - & - \\
\hline
\end{tabular}

Tabel 11. Spesifikasi Kelas user

\begin{tabular}{|c|c|c|c|c|}
\hline \multicolumn{5}{|c|}{ JENIS KELAS : master } \\
\hline \multicolumn{5}{|c|}{ NAMA KELAS : user } \\
\hline \multicolumn{5}{|c|}{ PRIMARY KEY : kode_user } \\
\hline \multicolumn{5}{|c|}{ FORGN KEY: - } \\
\hline NO & FIELD NAME & TYPE & WIDTH & KETERANGAN \\
\hline 1 & Kode_user & Varchar & 12 & - \\
\hline 2 & Nama & Varchar & 50 & - \\
\hline 3 & Username & Varchar & 25 & - \\
\hline 4 & Password & Varchar & 50 & - \\
\hline & No_telp & Varchar & 15 & \\
\hline & Alamat & Text & - & \\
\hline & Hak_akses & Varchar & 12 & \\
\hline
\end{tabular}

Tabel 12. Spesifikasi Kelas stok_sementara

\begin{tabular}{|c|c|c|c|c|}
\hline \multicolumn{5}{|c|}{ NIS KELAS : transa } \\
\hline \multicolumn{5}{|c|}{ NAMA KELAS : stok_sementara } \\
\hline \multicolumn{5}{|c|}{ PRIMARY KEY : - } \\
\hline \multicolumn{5}{|c|}{ FORGN KEY: - } \\
\hline NO & FIELD NAME & TYPE & WIDTH & KETERANGAN \\
\hline 1 & Kode_barang & Int & 12 & - \\
\hline 2 & Bulan_kemarin & Int & 5 & - \\
\hline 3 & Barang_masuk & Int & 5 & - \\
\hline 4 & Barang_keluar & Int & 5 & - \\
\hline 5 & Bulan_sekarang & Int & 5 & \\
\hline
\end{tabular}

Tabel 13. Spesifikasi Kelas stok_opname

\begin{tabular}{|c|c|c|c|c|}
\hline \multicolumn{5}{|c|}{ JENIS KELAS : mast } \\
\hline \multicolumn{5}{|c|}{ NAMA KELAS : stock_opname } \\
\hline \multicolumn{5}{|c|}{ PRIMARY KEY :- } \\
\hline \multicolumn{5}{|c|}{ FORGN KEY: - } \\
\hline $\mathrm{NC}$ & FIELD NAME & TYPE & WIDTH & KETERANGAN \\
\hline 1 & Kode_so & Varchar & 25 & - \\
\hline 2 & Tanggall & Date & & - \\
\hline 4 & Kode_barang & Int & 12 & - \\
\hline 5 & Bulan_kemarin & Int & 5 & - \\
\hline 6 & Barang_masuk & Int & 5 & - \\
\hline 7 & Barang_keluar & Int & 5 & - \\
\hline 8 & Bulan_sekarang & Int & 5 & \\
\hline 9 & adjust & Int & 5 & - \\
\hline 10 & keterangan & Text & 100 & \\
\hline
\end{tabular}

\section{c. Rancangan Prototype Antar Muka (User Interface)}

Pada bagian berikut ini, penulis akan menampilkan hasil perancangan user interface atau antar muka antara komputer dengan pengguna.

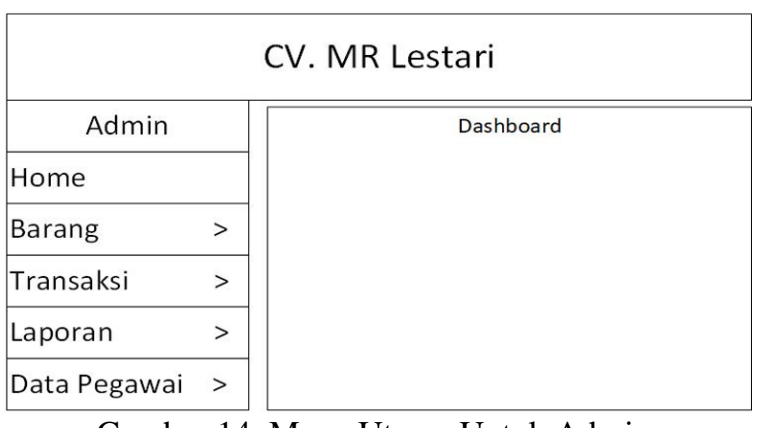

Gambar 14. Menu Utama Untuk Admin

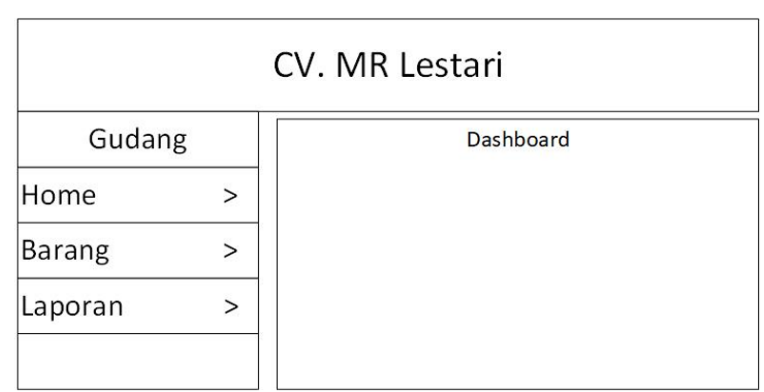

Gambar 15. Menu Utama Untuk Gudang 


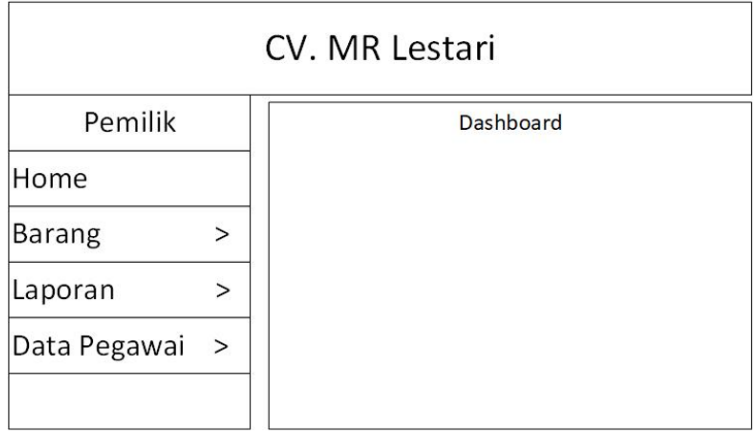

Gambar 16. Menu Utama Untuk Pemilik

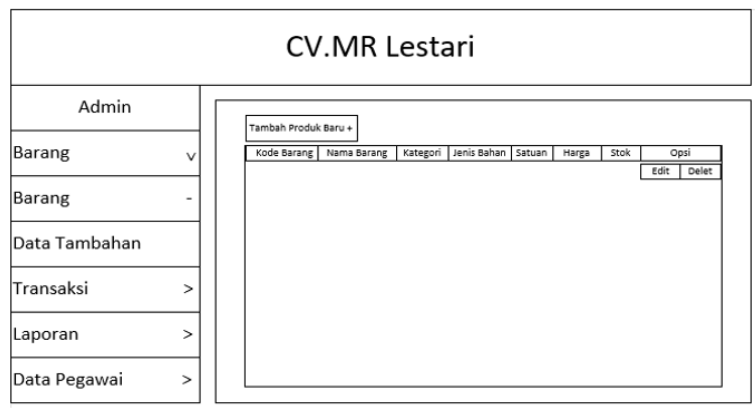

Gambar 17. Antar Muka Input Data Barang

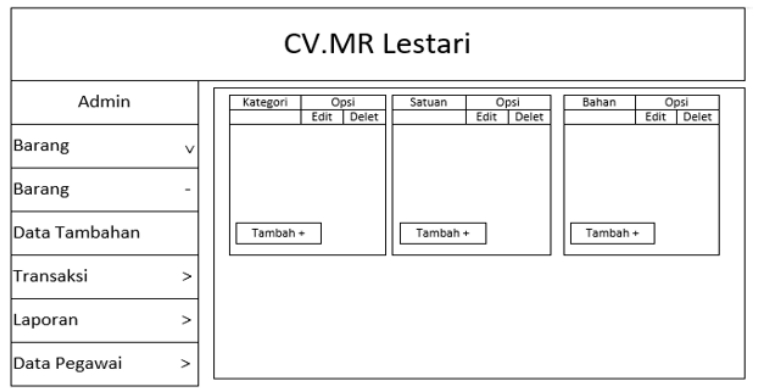

Gambar 18. Antar Muka Untuk Input Data Master: Kategori, Satuan Dan Bahan

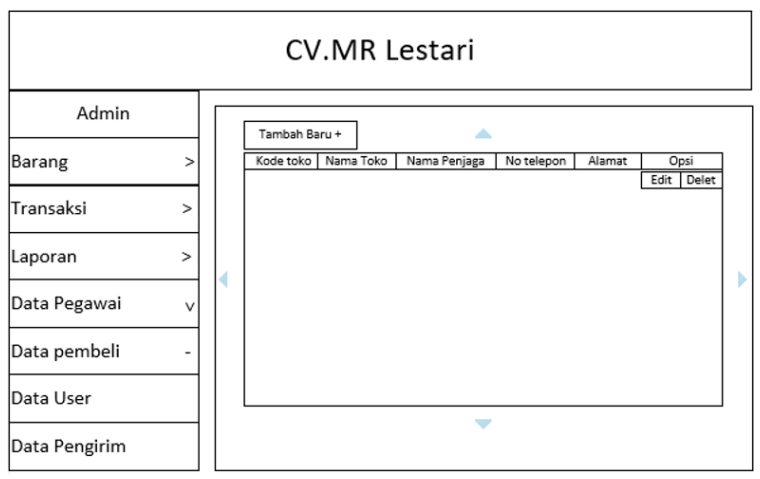

Gambar 19. Antar Muka Input Data Pembeli

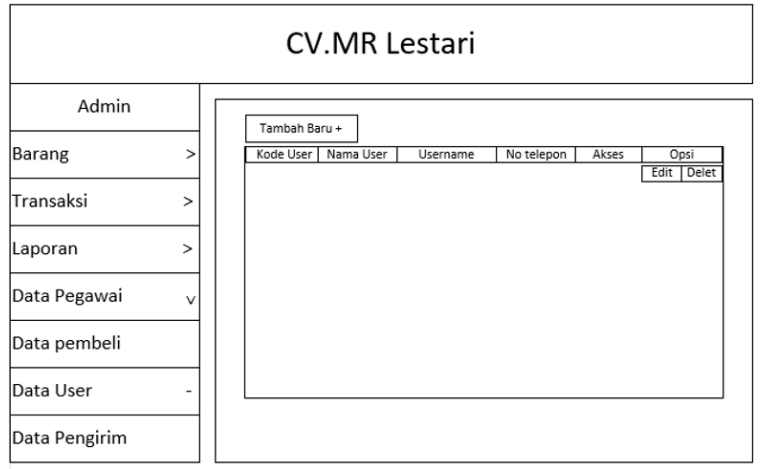

Gambar 20. Tampilan Input Data User

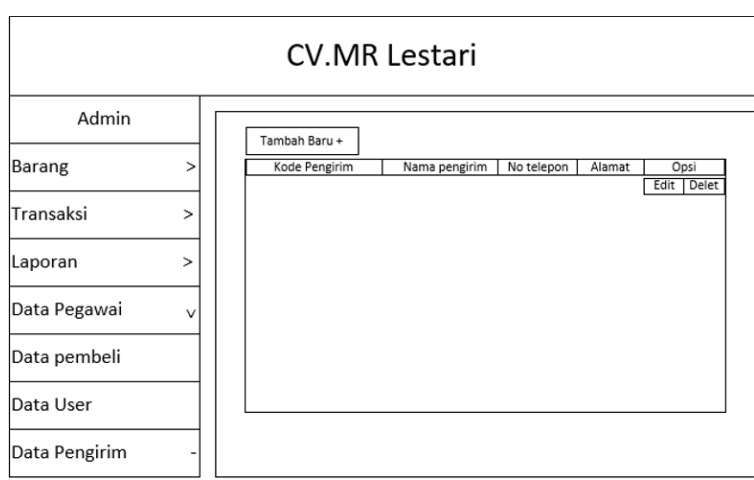

Gambar 21. Tampilan Input Data Pengirim

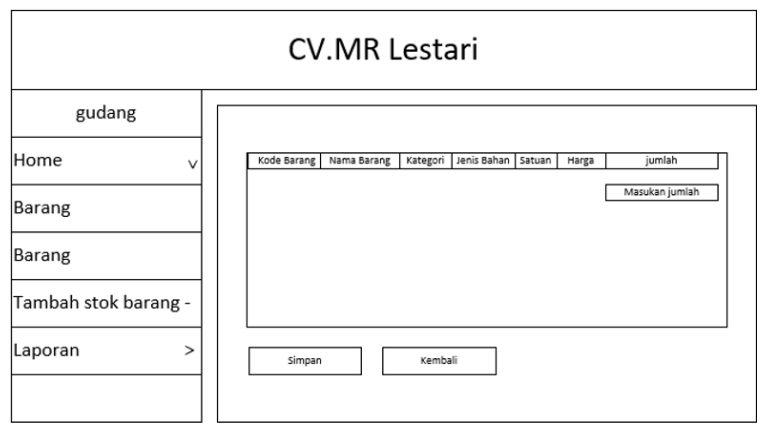

Gambar 22. Antar Muka Update Stok Di Gudang

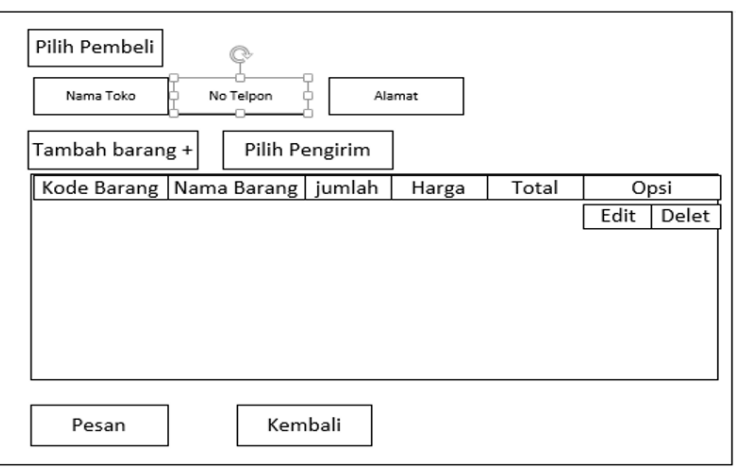

Gambar 23. Antar Muka Proses Kirim Barang 


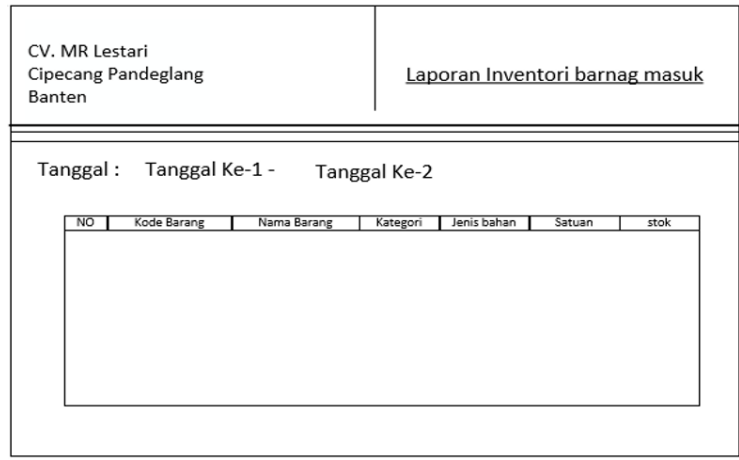

Gambar 24. Laporan Barang Masuk

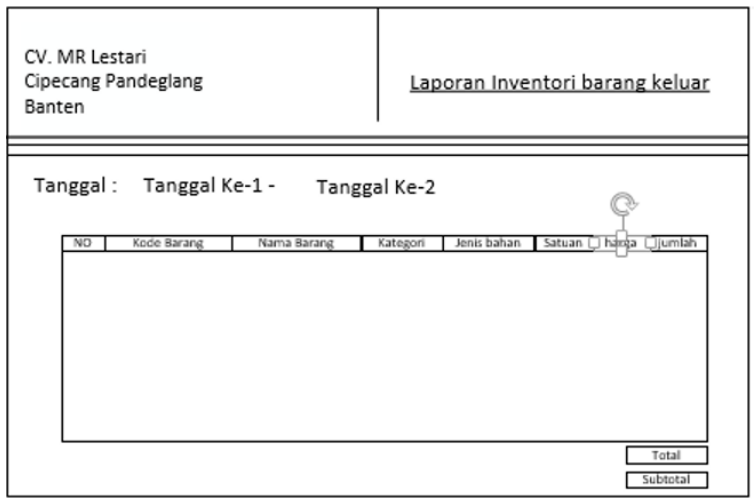

Gambar 25. Laporan Barang Keluar

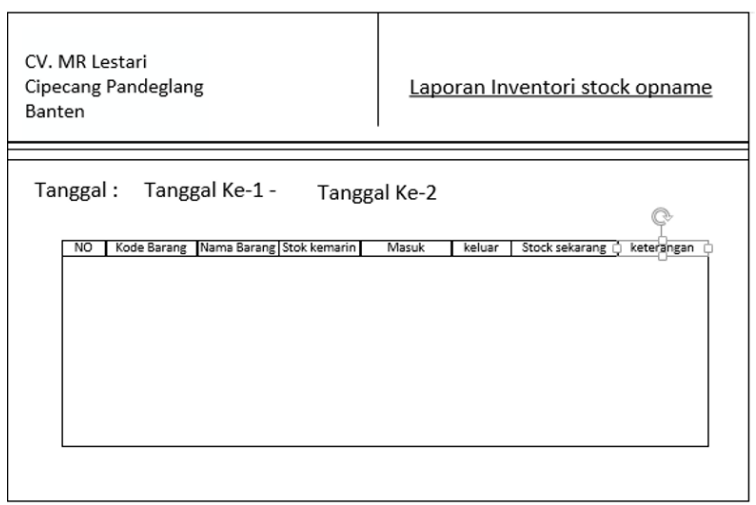

Gambar 26. Laporan Stock Opname

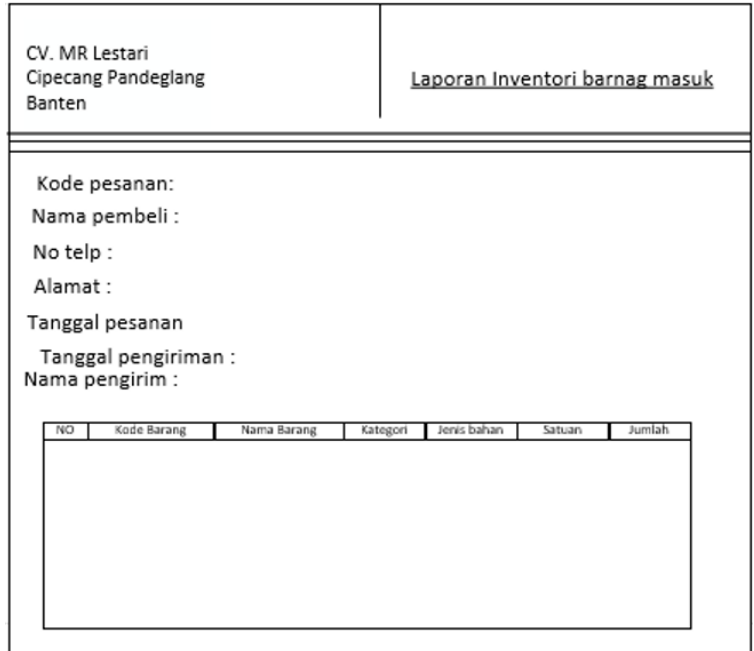

Gambar 27. Faktur Pengiriman

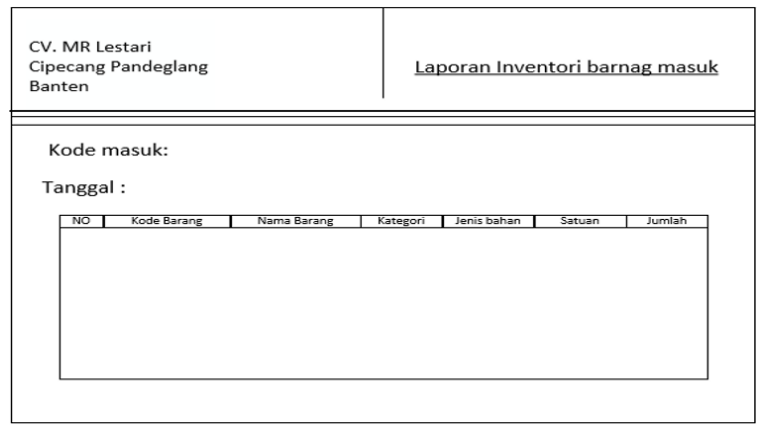

Gambar 28. Faktur Barang Masuk plotting unit dan driver

\subsection{Implementasi Dan Pengujian}

Setelah dilakukan programming, berikut akan ditampilkan hasil implementasi sistem berupa antar muka atau user interface beserta dengan hasil pengujian. 


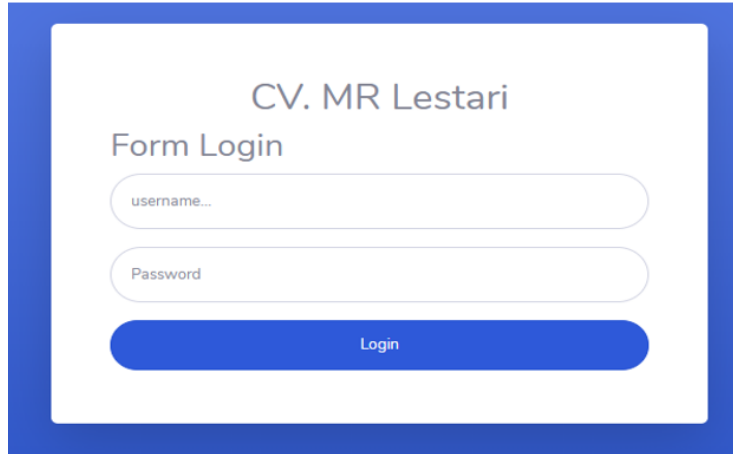

Gambar 29. Antar Muka Untuk Login

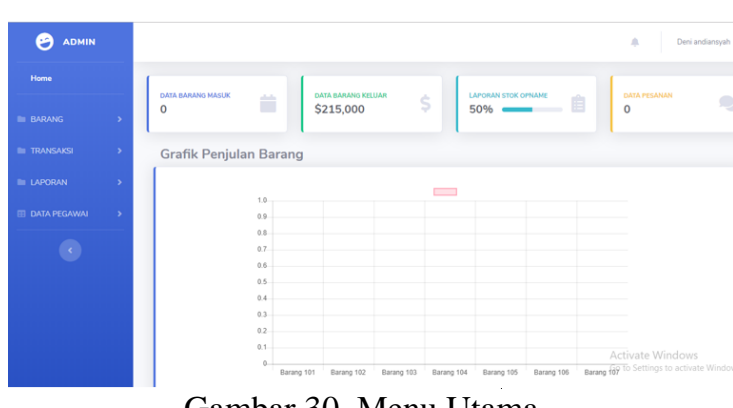

Gambar 30. Menu Utama

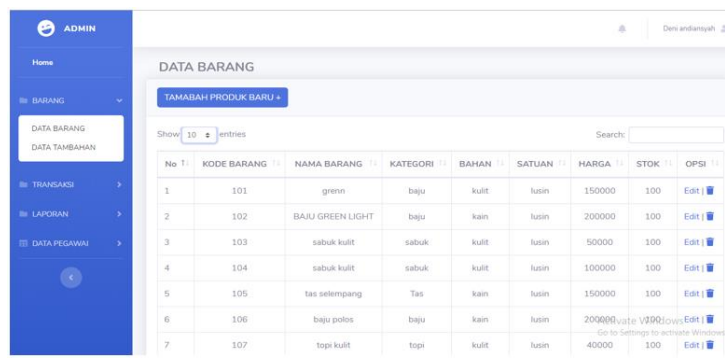

Gambar 31. Menu Input Barang

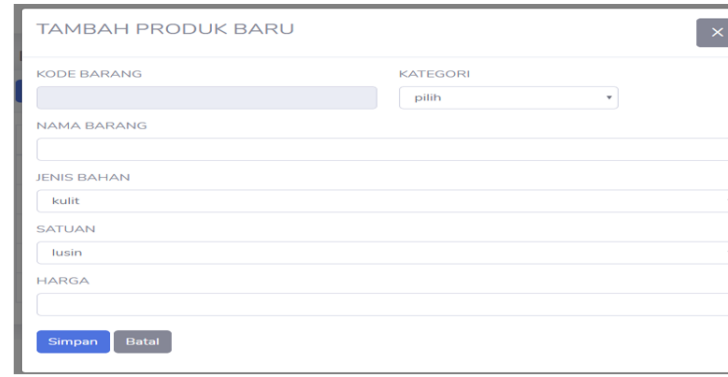

Gambar 32. Menu Tambah Barang

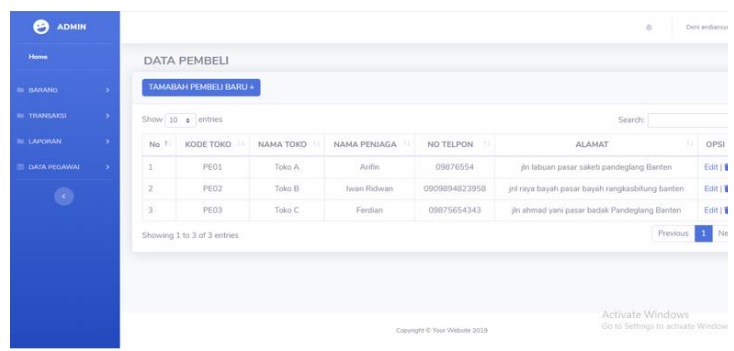

Gambar 33. Menu Pembeli

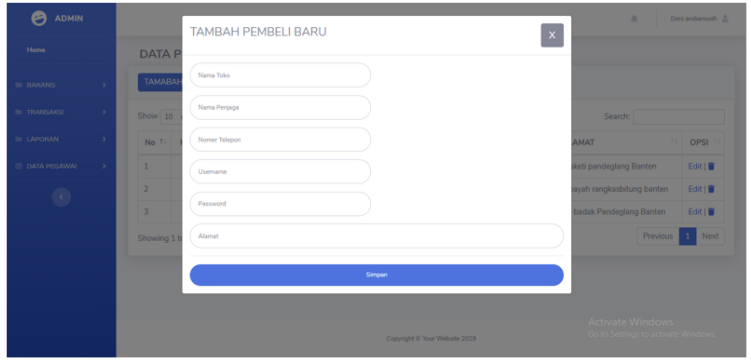

Gambar 34. Menu Tambah Pembeli
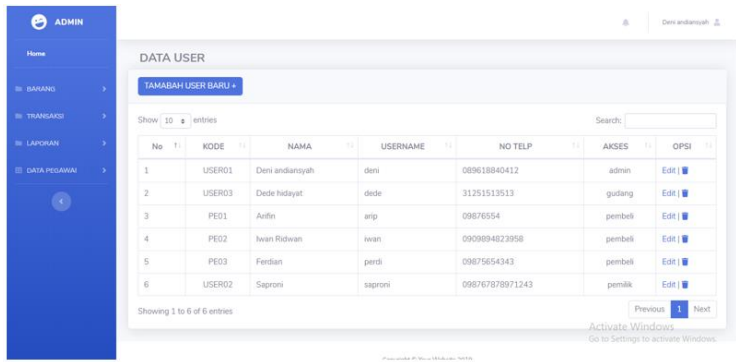

Gambar 35. Menu Data User

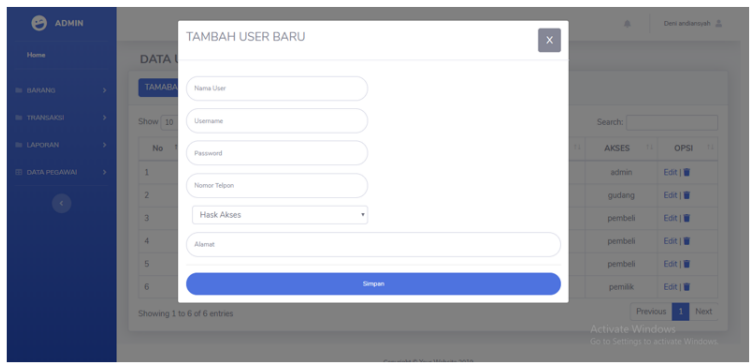

Gambar 36. Menu Tambah User

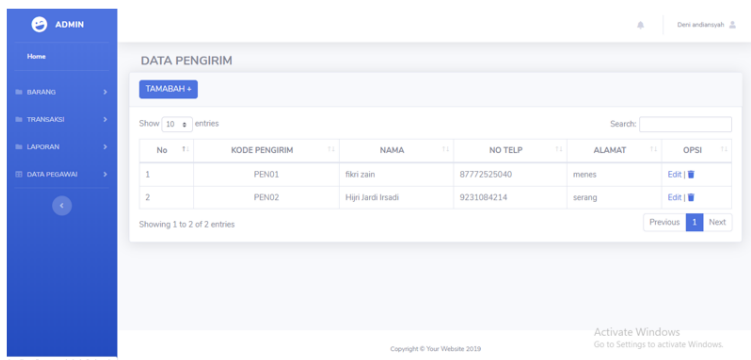

Gambar 37. Menu Data Pengiriman

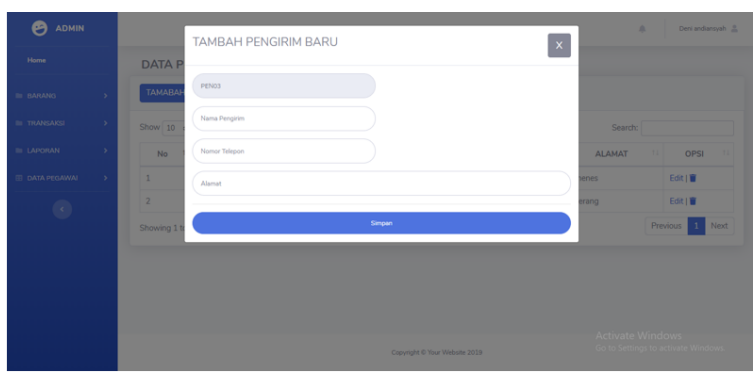

Gambar 38. Menu Tambah Pengiriman 


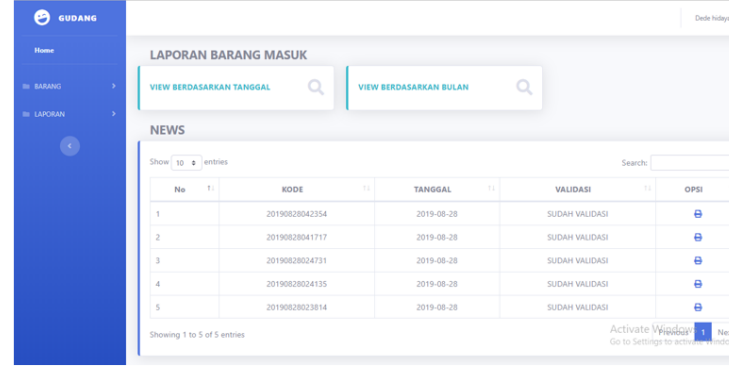

Gambar 39. Menu Barang Masuk

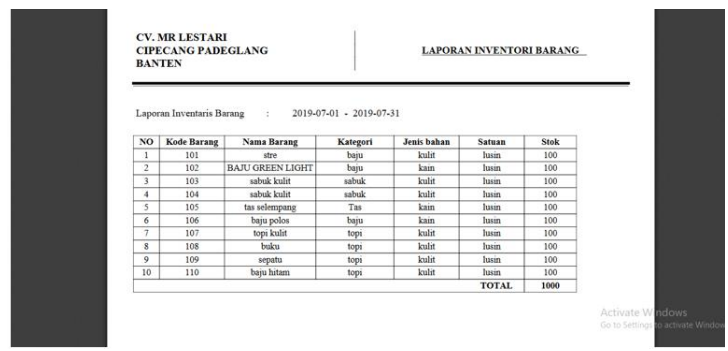

Gambar 40. Laporan Barang Masuk

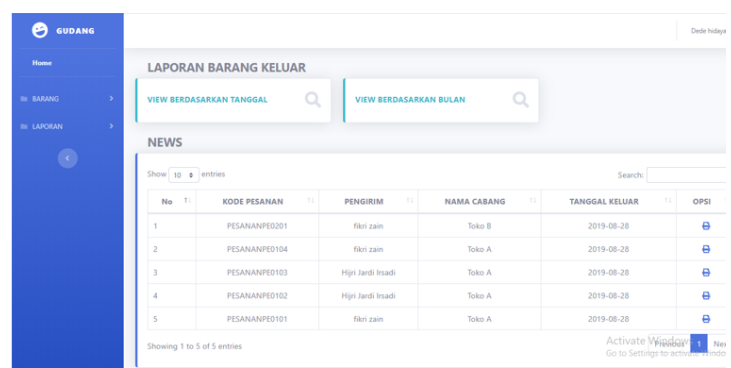

Gambar 41. Menu Barang Keluar

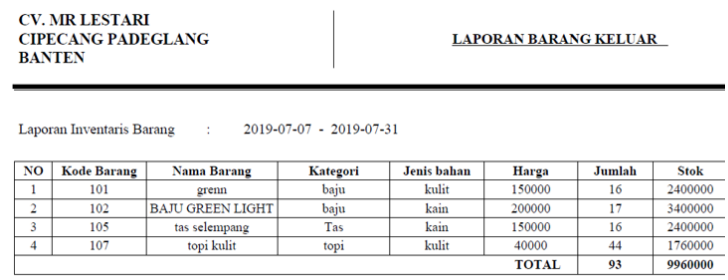

Gambar 42. Laporan Barang Keluar

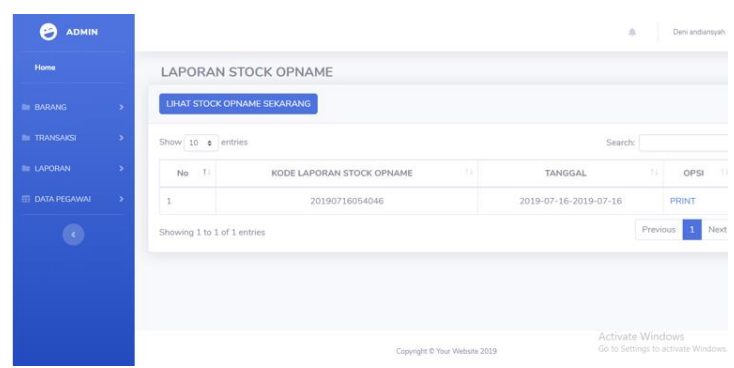

Gambar 43. Menu Stock Opname

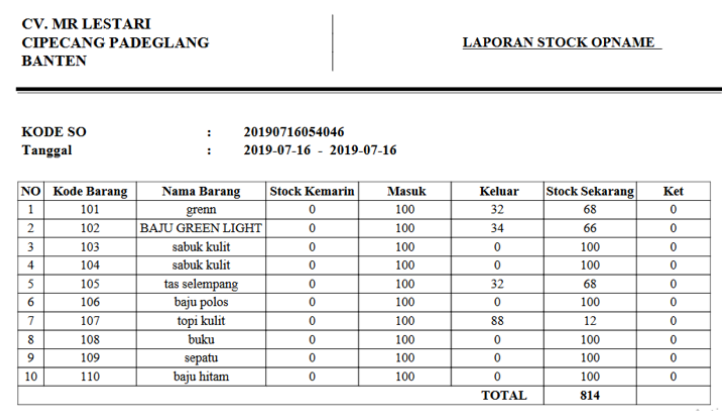

Gambar 44. Laporan Stock Opname

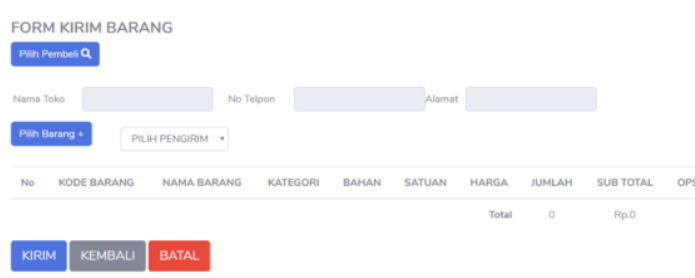

Gambar 45. Form Kirim Barang
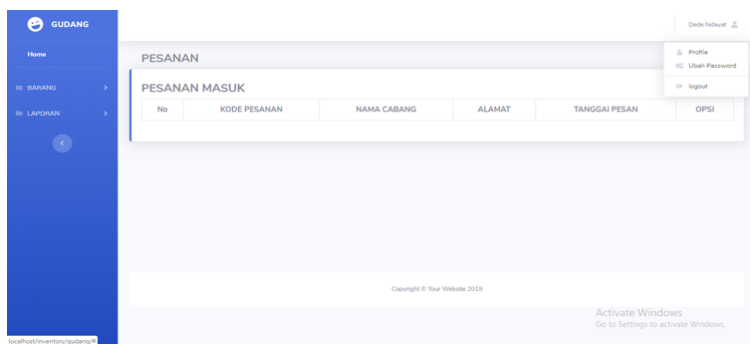

Gambar 46. Form Gudang
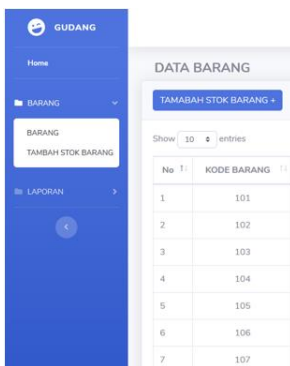

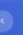

\begin{tabular}{|l|l|}
\hline 5 & ${ }^{105}$ \\
\hline 7 & ${ }_{107}$ \\
\hline
\end{tabular}

Gambar 47. Menu Tambah Barang

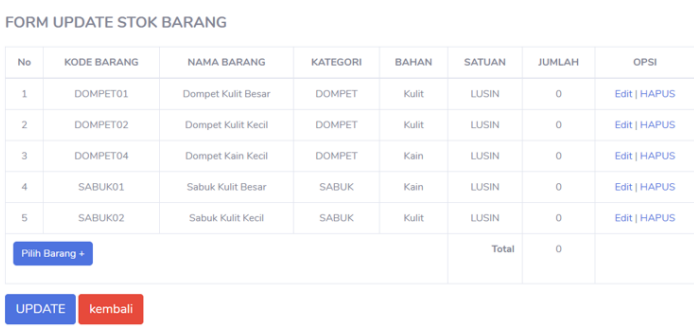

Gambar 48. Form Tambah Stok Barang 

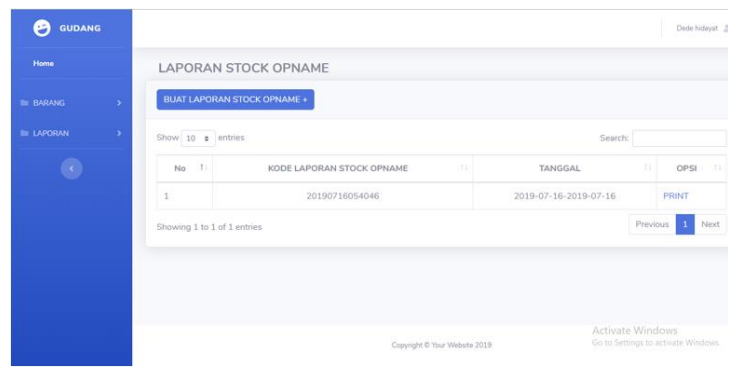

Gambar 49. Menu Stock Opname

Gambar 50. Laporan Stock Opname

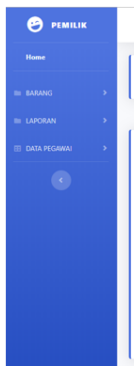

Gambar 51. Menu Utama Pemilik

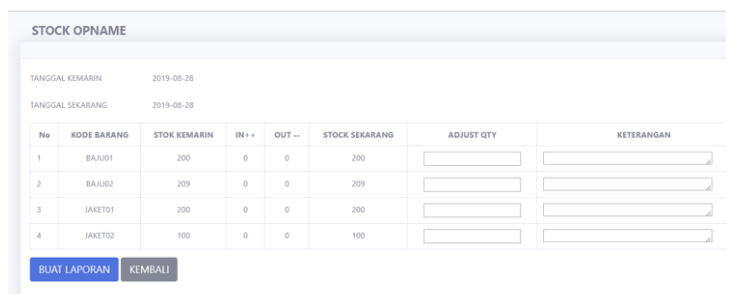

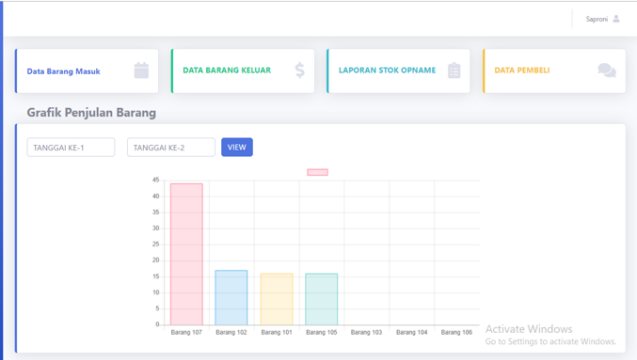

Hasil pengujian dilakukan secara black box, sehingga dapat diperoleh hasil seperti tabel berikut:

\begin{tabular}{|c|c|c|c|c|}
\hline $\begin{array}{l}\text { NO } \\
\text { UJI }\end{array}$ & KELAS UJI & $\begin{array}{c}\text { BUTIR } \\
\text { UJI }\end{array}$ & $\begin{array}{c}\text { TINGKAT } \\
\text { PENGUJIAN }\end{array}$ & $\begin{array}{c}\text { METODA } \\
\text { PENGUJAN }\end{array}$ \\
\hline 1 & $\begin{array}{l}\text { Menu Utma Admin, } \\
\text { gudang, pembeli } \\
\text { Pemilik }\end{array}$ & Menu utama & Pengujian sistem & Black Box \\
\hline \multirow[t]{3}{*}{2} & \multirow[t]{3}{*}{ Form Data barang } & Tambah & Pengujian sistem & Black Box \\
\hline & & Edit & Pengujian sistem & Black Box \\
\hline & & Hapus & Pengujian sistem & Black Box \\
\hline 3 & Tambah stok & Edit stok & Pengujian sistem & Black Box \\
\hline \multirow[t]{3}{*}{4} & \multirow[t]{3}{*}{ Form Pesan barang } & $\begin{array}{l}\text { Tambah } \\
\text { pesanan }\end{array}$ & Pengujian sistem & Black Box \\
\hline & & $\begin{array}{l}\text { Hapus } \\
\text { pesanan }\end{array}$ & Pengujian sistem & Black Box \\
\hline & & Edit jumlah & Pengujian sistem & Black Box \\
\hline 5 & Laporan & Laporan & $\begin{array}{l}\text { Pengujian } \\
\text { Sistem }\end{array}$ & Black Box \\
\hline \multirow[t]{3}{*}{6} & \multirow[t]{3}{*}{ Form data pembeli } & Tambah & Pengujian sistem & Black Box \\
\hline & & Edit & Pengujian sistem & Black Box \\
\hline & & Hapus & Pengujian sistem & Black Box \\
\hline \multirow[t]{3}{*}{7} & \multirow[t]{3}{*}{ Form data User } & Tambah & Pengujian sistem & Black Box \\
\hline & & Edit & Pengujian sistem & Black Box \\
\hline & & Hapus & Pengujian sistem & Black Box \\
\hline \multirow[t]{3}{*}{8} & \multirow[t]{3}{*}{ Form data Pengirim } & Tambah & Pengujian sistem & Black Box \\
\hline & & Edit & Pengujian sistem & Black Box \\
\hline & & Hapus & Pengujian sistem & Black Box \\
\hline
\end{tabular}

Tabel 14. Hasil Pengujian 


\section{KESIMPULAN}

Berdasarkan hasil penelitian yang dilakukan pada CV. MR Lestari, dapat disimpulkan sebagai berikut:

a) Dengan sistem informasi penjulan dan inventori yang sudah terkomputerisasi otomatis dapat mengatasi masalah penyimpanan data penjualan dan inventori barang yang sebelumnnya masih manual dan mengurangi kesalahan dalam pengelolaan data barang dan proses pembuatan laporan.

b) Dengan terbentuknya sebuah sistem maka dapat mempercepat pada proses pendataan pesanan dan dapat meningkatkan pelayanan yang baik kepada pembeli.

c) Dengan adanya sistem berbasis komputer maka pemilik dapat mengetahui perkembangan usahanya tersebut dari laporan yang di buat otomatis oleh sistem yang sebelumnnya menggunkan arsip atau catatan manual.

Setelah penulis melakukan penelitian dan mencoba untuk membuat pemodelan masalah serta merancang suatu sistem informasi berbasis web untuk dapat menyelesaikan masalah yang ada, maka ada beberapa saran yang dapat disampaikan yaitu:

a) Admin sistem informasi yang telah dirancang, harus diberikan pelatihan dan pengetahuan dibidang komputer, agar admin dapat mengetahui cara mengentri data dan mengamankan data yang ada.

b) Perlu adanya pemeliharaan, pengawasan serta evaluasi terhadap sistem yang baru secara berkala. Sehingga akan terkontrol dan cepat mengambil tindakan dengan melakukan perubahan sistem jika terdapat perubahan prosedur atau aturan baru.

\section{DAFTAR PUSTAKA}

Pressman, R.S. 2002. "Rekayasa Perangkat Lunak: Pendekatan Praktis“. Yogyakarta: Penerbit Andi.

Sommerville, I. 2011. "Software Engineering $9^{\text {th }}$ Edition". United States of America: Addison-Wesley.

Triyono, G. 2011. "Pertimbangan Melakukan Denormalisasi Pada Model Basis Data Relasi" dalam Jurnal TELEMATIKA MKOM, Vol.3 No,2 (hlm. 19).

Nugroho, Adi. 2005. "Rational Rose untuk Pemodelan Berorientasi Objek". Bandung: Informatika.

Rumbaugh, James et.all.1999. "The Unified Modeling Language". United States of America: Addison Wesley Longman, Inc. 